\title{
Counter-current attrition process (CCAP) to remove metals, pentachlorophenol (PCP), dioxins and furans (PCDDF) from the 1-4-mm fraction of contaminated soil
}

\section{Karima Guemiza ${ }^{1}$ Lucie Coudert ${ }^{2} \cdot$ Lan Huong $\operatorname{Tran}^{3} \cdot$ Sabrine Metahni ${ }^{4} \cdot$ Jean-Francois Blais $^{5} * \cdot$ Simon Besner ${ }^{6} \cdot$ Guy Mercier $^{7}$}

1 Ph.D. student, Institut national de la recherche scientifique (Centre Eau, Terre et Environnement), Université du Québec, 490 rue de la Couronne, Québec, QC, Canada, G1K 9A9, Phone: (418) 654-5648, Fax: (418) 654-2600, email: karima.gmiza@ete.inrs.ca

2 Research associate, Institut national de la recherche scientifique (Centre Eau, Terre et Environnement), Université du Québec, 490 rue de la Couronne, Québec, QC, Canada, G1K 9A9, Phone: (418) 654-3793, Fax: (418) 654-2600, email: lucie.coudert@ete.inrs.ca

3 Research associate, Institut national de la recherche scientifique (Centre Eau, Terre et Environnement), Université du Québec, 490 rue de la Couronne, Québec, QC, Canada, G1K 9A9, Phone: (418) 654-2550, Fax: (418) 654-2600, email: lan.huong.tran@ete.inrs.ca

4 Ph.D. student, Institut national de la recherche scientifique (Centre Eau, Terre et Environnement), Université du Québec, 490 rue de la Couronne, Québec, QC, Canada, G1K 9A9, Phone: (418) 654-4677, Fax: (418) 654-2600, email: sabrine.metahni@ete.inrs.ca

5 Professor, Institut national de la recherche scientifique (Centre Eau, Terre et Environnement), Université du Québec, 490 rue de la Couronne, Québec, QC, Canada, G1K 9A9, Phone: (418) 654-2575, Fax: (418) 654-2600, email: blaisjf@ete.inrs.ca

6 Research Scientist, Institut de recherche d'Hydro-Québec (IREQ), IREQ, 1800, boul. Lionel-Boulet, Varennes, QC, Canada, J3X 1S1, Phone: 1 (450)-652-8318, Fax: 1 (450)652-8424, email: besner.simon@ireq.ca

7 Professor, Institut national de la recherche scientifique (Centre Eau, Terre et Environnement), Université du Québec, 490 rue de la Couronne, Québec, QC, Canada, G1K 9A9, Phone: (418) 654-2633, Fax: (418)654-2600, email: guy.mercier@ete.inrs.ca

\section{(*) Corresponding author}

September 2017 


\section{Abstract}

2 The objective of this study was to evaluate the potential of a counter-current attrition process

3 (CCAP) over 15 cycles for removing metals, pentachlorophenol (PCP) and polychlorinated

4 dibenzo-p-dioxins and -furans (PCDDF) from contaminated soil. The CCAP, applied to the 1-4-

$5 \mathrm{~mm}$ fraction of a contaminated soil, included five attrition steps (pulp density (PD) $=40 \%$ ( $\mathrm{w} \mathrm{w}^{-}$

$\left.6^{1}\right)$, surfactant $\left.[\mathrm{BW}]=2 \%\left(\mathrm{w} \mathrm{w}^{-1}\right), \mathrm{t}=20 \mathrm{~min}, \mathrm{~T}=20^{\circ} \mathrm{C}\right)$ followed by one rinsing step. The water

7 emerging from the first attrition step was treated using flocculation in the presence of

80.04 g CMX 123 (commercial flocculent) $\mathrm{L}^{-1}$ before being reintroduced into the CCAP. The

9 CCAP including the treatment of attrition wastewater (ATW) by flocculation achieved a removal

10 of $44 \pm 5 \%$ As, $26 \pm 6 \%$ Cr, $24 \pm 5 \% \mathrm{Cu}, 49 \pm 4 \%$ PCP and $45 \pm 3 \%$ PCDDF. Moreover, the

11 CCAP enabled a significant reduction (78\%) in the amount of water required (around $14.5 \mathrm{~m}^{3}$ of

12 water per ton of the 1-4-mm soil fraction). The high removal yields obtained after 15 attrition

13 cycles of the CCAP for PCP and PCDDF and the significant reduction of water consumption

14 confirm that this CCAP can be considered for industrial applications.

16 Keywords: Attrition • Counter-current • Contaminated soil • Pentachlorophenol • Polychloro-

17 dibenzodioxins and furans $\bullet$ Metals 


\section{$1 \quad 1 \quad$ Introduction}

2 Soil contamination is a global concern and is considered a serious environmental problem that

3 affects the health of humans and the ecosystem. Soil contamination is the result of industrial

4 activities or inadequate waste disposal (Han et al., 2002; Wuana et al., 2011; Pohren et al., 2012;

5 Coronas et al., 2016). This contamination leads to an increase in the concentration of inorganic

6 (e.g., As, Cd, Cr, Cu, Ni, Pb, Se, and $\mathrm{Zn}$ ) and organic compounds (e.g., polycyclic aromatic

7 hydrocarbons (PAHs), pentachlorophenol (PCP), polychlorinated dibenzo-p-dioxins and -furans

8 (PCDDF)) present in soils. Chlorophenol compounds are known as one of the most important

9 precursors leading to the formation of PCDDF (Holt et al., 2009).

10 Several efforts are being made across the world to develop technologies that can efficiently

11 rehabilitate sites contaminated by both inorganic and organic compounds and that currently

12 require a series of complex decontamination processes (USEPA, 2004). Destructive techniques,

13 including incineration or dechlorination methods, are effective for the removal of organic

14 contaminants such as PCP and PCDDF. However, these solutions are very expensive (Metahni,

15 2013) and are not effective at removing metals. Among the separative methods, thermal

16 desorption seems to be the only method that can be used for the removal of PCP and PCDDF

17 from contaminated soils (Young et al., 2000; Thuan and Chang, 2012; Thuan et al., 2013; Li et

18 al., 2014). Presently, this technology is used at the industrial scale for the removal of organic

19 compounds present in contaminated soils, despite the high costs (Dai et al., 2013; Lundin et al.,

20 2013; Zhao et al., 2013; Tritz et al., 2014). However, at temperatures lower than $400^{\circ} \mathrm{C}$, the

21 application of thermal desorption to soils contaminated with chlorinated compounds may result

22 in the formation of highly toxic compounds such as 2,3,7,8-tetra-CDD (Speir et al., 1997;). In

23 addition, an inadequate retention time may lead to increased toxicity of the PCDDF compounds 
1 present in soils due to their incomplete destruction (Hung et al., 2016). Bioremediation methods

2 have been used to remediate contaminated soils (Liu et al., 2014; Tu et al., 2014; Zhen et al.,

3 2014), but they are not effective at removing toxic compounds such as PCDDF and inorganic

4 contaminants when they are present in high concentrations.

5 Over the past several decades, several authors have studied physical and chemical

6 decontamination processes to evaluate their ability to simultaneously remove inorganic and

7 organic compounds from solid matrices, including soils (Riveiro-Huguet and Marshall, 2011;

8 Bisone et al., 2013a; Reynier et al., 2013a, b; Guemiza et al., 2016; Metahni et al., 2016). The

9 attrition uses high-intensity agitation to remove films around soil particles and/or to detach fine

10 particles from the surface of coarse particles, resulting in the release of contaminants. Among the

11 physical treatments (aqueous-based separation) developed, the attrition process is the most

12 commonly used technology to remove both organic and inorganic contaminants from

13 contaminated soils. The attrition process is governed by the physical contact between the

14 contaminated particles themselves, the contact between the contaminated particles and the liquid

15 phase, and the walls and the impellers present in the mixing reactor, which favor the removal of

16 the fine particles that contain the contaminants. As most of the contaminants present in soil

17 usually have low water solubility, such additives as acids, alkaline agents, surfactants and/or

18 chelating agents are often added into the attrition pulp to improve the removal of both inorganic

19 (e.g., As, $\mathrm{Cr}, \mathrm{Cu}, \mathrm{Pb}$, and $\mathrm{Zn}$ ) and organic compounds (e.g., PAHs, PCP, and PCDDFs) (Riveiro-

20 Huguet and Marshall, 2011; Bisone et al., 2013a; Reynier et al., 2013b; Guemiza et al., 2016;

21 Metahni et al., 2016). Surfactants are compounds that contain both hydrophilic and hydrophobic

22 parts in their molecular structure. The use of surfactants during attrition washing seems to be a

23 highly efficient method for the simultaneous removal of inorganic and organic contaminants. 
1 Attrition processes may be used with or without a surfactant to remove organic compounds (e.g.,

2 PCP and PCDDF) from contaminated soils. The attrition process performed by Bisone et al.

3 (2013a) that used a surfactant ([cocamidopropyl hydroxysultaine, CAS] $=0.2 \mathrm{~g} \mathrm{~L}^{-1}$ ) achieved a

4 removal of more than $90 \%$ of PAHs from contaminated soil. The decontamination process

5 developed by Veetil et al. (2014) consisted of froth flotation (fractions $<250 \mu \mathrm{m}$ ), a Wilfley

6 table $(0.250-2 \mathrm{~mm})$ and a physical separation column preceded by an attrition step as pre-

7 treatment (> $2 \mathrm{~mm}$ ). This process achieved a removal of $71 \%$ to $80 \%$ of PAHs, $61 \%$ to $65 \%$ of

$8 \mathrm{Cu}, 27 \%$ to $33 \%$ of $\mathrm{Zn}$ and $36 \%$ to $40 \%$ of $\mathrm{Pb}$. Organic compounds with high molecular weights

9 (e.g., mineral oils, such as Catenex S341) present in contaminated soils seemed to be

10 successfully extracted using an attrition process (Bayley and Biggs, 2005). According to Jobin et

11 al. (2015), the effectiveness of attrition was positively correlated with the size of soil particles.

12 Recently, Jobin et al. (2016) applied one attrition step ( $\mathrm{PD}=30 \%, \mathrm{t}=10 \mathrm{~min}, \mathrm{~T}=25^{\circ} \mathrm{C}$ ) as a

13 pre-treatment to the physical technique of separation (gravity separation, elutriation column) to

14 treat the $0.250-4-\mathrm{mm}$ fraction of a soil contaminated by both organic and inorganic compounds.

15 This sequence of decontamination processes allowed for the removal of $50 \% \mathrm{Cu}, 64 \% \mathrm{~Pb}$, and

$1640 \%$ PAHs. Metahni et al. (2016) studied the use of an attrition process without any surfactant to

17 treat the coarse fractions (> $125 \mu \mathrm{m}$ ) of soils contaminated by As, $\mathrm{Cr}, \mathrm{Cu}, \mathrm{PCP}$ and PCDDF. The

18 removal yields obtained ranged from 22 to $43 \%$ for As, from 0 to $13 \%$ for $\mathrm{Cr}$, from 23 to $46 \%$

19 for $\mathrm{Cu}$, from 0 to $85 \%$ of PCP and from 17 to $64 \%$ for PCDDF. These results showed that the

20 nature of the soil and the type and initial level of the contaminants can influence the efficiency of

21 the attrition process. Recently, Guemiza et al. (2016) showed that an attrition process (five

22 attrition steps, $1-4-\mathrm{mm}$ soil fraction, $\mathrm{PD}=40 \%, \mathrm{~T}=25^{\circ} \mathrm{C}$, surfactant concentration 
1 [cocamidopropylbetaine: $\mathrm{BW}$ ] $=2 \%, \mathrm{t}=20 \mathrm{~min}$ ) achieved a removal of 56\%, 55\%, 50\%, 67\%

2 and $62 \%$ of As, $\mathrm{Cr}, \mathrm{Cu}, \mathrm{PCP}$ and PCDDF, respectively, from a contaminated soil.

3 This research project aims to study the possibility of recirculating water into a multi-step attrition

4 process using a counter-current attrition process (CCAP) without influencing the performance of

5 this process in terms of removing both inorganic and organic compounds from the 1-4-mm soil

6 fraction. A coagulation-flocculation process using organic polymers was also studied to reduce

7 the suspended organic matter content in the attrition wastewaters, so that it could be recycled into

8 the attrition process without impacting the decontamination performance.

\section{$9 \quad 2 \quad$ Materials and Methods}

\section{$10 \quad 2.1$ Soil sampling and characterization}

11 In this study, contaminated soil located in an industrial area in Canada was sampled at a depth of

120 to $15 \mathrm{~cm}$ and called $\mathrm{J} 3$. The soil samples were collected within the first $15 \mathrm{~cm}$ because several

13 researchers highlighted that both inorganic (As, $\mathrm{Cr}$ and $\mathrm{Cu}$ ) and organic contaminants (PCP and

14 PCDD/F) are mainly immobilized in the top soil, between 0 and $15 \mathrm{~cm}$ (Chirenje et al., 2013;

15 Lespagnol, 2003; Isosaari, 2004). The soil was preserved in 25-L high-density polyethylene

16 (HDPE) containers and stored at room temperature. Next, the soil was sieved using a mechanical

17 Sweco $^{\mathrm{TM}}$ and different sieves $(12 \mathrm{~mm} ; 4 \mathrm{~mm} ; 1 \mathrm{~mm}$ and $0.250 \mathrm{~mm}$ ) to get different soil fractions.

18 Previous experiments have been done to characterize the contamination of the different soil

19 fractions; highlighting that the $1-4 \mathrm{~mm}$ soil fractions represented $28 \%$ of the entire soil and its

20 contamination was representative of the coarse fractions $(>0.25 \mathrm{~mm})$. Therefore, the 1-4-mm

21 soil fraction was kept and dried at $60^{\circ} \mathrm{C}$ overnight before being used for the counter-current

22 attrition process (CCAP) experiments. 


\section{$1 \quad 2.2$ Counter-current attrition process}

2 During this study, the attrition steps were conducted in a 10-L stainless reactor equipped with

3 internal baffles with $2 \mathrm{~kg}$ of the 1-4-mm J3 soil fraction. Five attrition steps were performed

4 under the optimized operating conditions defined by Guemiza et al. (2016): tap water, pulp

5 density $\quad(\mathrm{PD})=40 \% \quad\left(\mathrm{w} \cdot \mathrm{w}^{-1}\right), \quad[\mathrm{BW}]=2 \% \quad\left(\mathrm{w} \mathrm{w} \mathrm{w}^{-1}\right), \quad \mathrm{t}=20 \mathrm{~min}, \quad \mathrm{~T}=20^{\circ} \mathrm{C}, \quad$ mixing

6 speed $=1,700$ rpm. The pulp was shaken using a mechanical stirrer (Light EV1 P25, AXFLOW,

7 New York, NY, USA) equipped with a stainless steel axial propeller (6 cm diameter) at

8 1,700 rpm. After each attrition step, the soil was sieved through a 0.5-mm sieve and washed with

$94 \mathrm{~L}$ of tap water before being returned to the process until a total of five attrition steps (AT 1,

10 AT 2, AT 3, AT 4 and AT 5) were achieved. After the $5^{\text {th }}$ stage of attrition, the 1-4-mm soil

11 fraction was washed with $4 \mathrm{~L}$ of water in a 20-L HDPE container using a Karcher (Karcher,

12 electric sprayer, 2000 lb.po-2 ${ }^{-2}$ Quebec, QC, Canada) before being sieved through a 0.5-mm sieve.

13 Then, the attrited soil was washed with $2 \mathrm{~L}$ of tap water.

14 Fifteen attrition cycles (loop 1 to loop 15) were conducted throughout this experiment, as shown

15 in Fig. 1. The first series of five attrition steps (loop 1) was conducted using fresh water, and the

16 attrition wastewaters were reused in the following cycles (loop 2 to loop 15). For example, the

17 effluent emerging from the fifth attrition step (ATT 5) of loop 1 has been used to perform the

18 fifth attrition step (ATT 5) of loop 2 while the effluents emerging from the second (ATT 2), the

19 third (ATT 3) and the fourth (ATT 4) attrition steps of loop 1 have been used to perform the first

20 (ATT 1), the second (ATT 2) and the third (ATT 3) of loop 2, respectively. The effluent

21 emerging from the first attrition step (ATT 1) of loop was treated by flocculation before to be

22 used to perform the fourth attrition step (ATT 4) of loop 2. At the end of each attrition cycle (five

23 attrition steps), the remaining soil was collected and dried at $60^{\circ} \mathrm{C}$ in an oven, and the remaining 
1 concentrations of PCP, PCDDF and metals were measured to evaluate the performance of the

2 treatment.

\section{$3 \quad 2.3$ Removal of contaminants from attrition wastewaters by coagulation-flocculation}

4 In the first series of experiments, the removal of organic contaminants from the attrition

5 wastewater (ATW) was studied using chemical coagulation-flocculation. This ATW emerged

6 from the first attrition step (ATW1) carried out on the 1-4-mm J3 soil fraction using the

7 following operating conditions defined by Guemiza et al. (2016): tap water, pulp density

$8(\mathrm{PD})=40 \%\left(\mathrm{w} \mathrm{w}^{-1}\right)$, cocamidopropylbetaine concentration $[\mathrm{BW}]=2 \%\left(\mathrm{w} \mathrm{w}^{-1}\right), \mathrm{t}=20 \mathrm{~min}$,

$9 \mathrm{~T}=20^{\circ} \mathrm{C}$, mixing speed $=1,700 \mathrm{rpm}$. Coagulation-flocculation experiments were conducted in

10 the presence of various polymers (8 polymers: Magnafloc 1011, Magnafloc 919, Magnafloc 10,

11 AMX 232, CTE 176, Percol 9511, Zetag 7654 and CMX 123) (Ciba Specialty Chemicals

12 Canada, Mississauga, ON, Canada). These flocculants have different cationic or anionic

13 functional groups and are most commonly used to treat municipal and industrial wastewaters. An

14 aqueous solution of $1 \mathrm{~g} \mathrm{~L}^{-1}$ of polymer was prepared for each polymer studied by diluting $1 \mathrm{~g}$ of

15 polymer into one liter of tap water in a 2-L beaker and mixing the solution vigorously for $20 \mathrm{~min}$

16 with a magnetic stirrer. These polymers were later used at different concentrations, and the

17 settling time was fixed at $1 \mathrm{~h}$. For some experiments, a solution of ferric chloride (Chemco Inc.,

18 Saint-Augustin-de-Desmaures, QC, Canada, $11 \%$ of iron $\left(\mathrm{w} \mathrm{w}^{-1}\right)$ ) was used. The effectiveness of

19 the coagulation-flocculation was determined visually (formation and size of the flocs, clarity of

20 the supernatant) and by measuring the total suspended solids (TSS) in the liquid phase (Method,

21 MA. 115- S.S. 1.2).

22 The coagulation-flocculation experiments were performed with two different volumes of ATW1:

$23500 \mathrm{~mL}$ and $1 \mathrm{~L}$. The first series of tests was conducted in 500-mL Erlenmeyer flasks to 
1 determine the best combination of coagulant/flocculent that should be used, whereas the second

2 series of experiments was performed in 1-L Imhoff cones to validate the observations made in

3 the small scale tests. The concentrations of As, $\mathrm{Cr}, \mathrm{Cu}, \mathrm{PCP}$ and PCDDF were determined in the

4 ATW before and after coagulation and in the coagulation sludge, which was recovered after $1 \mathrm{~h}$

5 of settling.

\section{$6 \quad 2.4 \quad$ Analytical methods}

7 The $\mathrm{pH}$ was determined according to the method described by the Quebec Expertise Center for

8 Environmental Analysis (MA. 100 - pH 1.1) (CEAEQ, 2014a) using a pH-meter (Accumet

9 Research AR25 Dual Channel pH/Ion meter, Fischer Scientific Ltd., Nepean, ON, Canada)

10 equipped with a double junction Cole-Parmer electrode with a $\mathrm{Ag} / \mathrm{AgCl}$ reference cell. The total

11 suspended solids were measured according to the CEAEQ method (MA.115 - S.S. 1.2) (CEAEQ,

12 2015). The total carbon (C) and organic carbon were analyzed according to the method CSNH

13412.1 (Hedges and Stern 1984) using a CHNS Leco analyzer (LECO TruSpec ${ }^{\circledR}$ Micro CHNS

14 932, Michigan, USA).

15 Metals and metalloid contents were measured in the 1-4-mm fraction of each soil sample (dry

16 basis) using an ICP-AES (inductively coupled plasma - atomic emission spectroscopy, Vista Ax

17 CCO simultaneous ICP-AES from Varian, Mississauga, ON, Canada) after the digestion of $0.5 \mathrm{~g}$

18 of each soil sample according to the Method MA. 200 - Mét-P ass. 1.0 (CEAEQ, 2014b) using

19 different acids $\left(\mathrm{HNO}_{3}\right.$ and $\left.\mathrm{HCl}\right)$. Analytical quality control was performed by analyzing certified

20 standard solutions (Multi-elements Standard 900-Q30-100, SCP Science, Lasalle, QC, Canada)

21 and certified soil samples (SQC 001-Lot 011233). PCP analysis was performed using gas

22 chromatography coupled with mass spectrometry (GC-MS) (Perkin Elmer, model Clarus 500,

23 column type RXi-17, $30 \mathrm{~m} \times 0.25 \mathrm{~mm} \times 0.25 \mu \mathrm{m}$ ) according to the CEAEQ method MA. 400- 
1 Phe. 1.0 (CEAEQ, 2013). The analysis of the 17 PCDDF congeners was performed using a GC-

2 MS (Thermo Scientific, model Trace 1310 Gas Chromatograph coupled with a mass

3 spectrometer detector ISQ, column type ZB Semi-volatile, $60 \mathrm{~m} \times 0.25 \mathrm{~mm} \times 0.25 \mu \mathrm{m}$ )

4 according to the CEAEQ method MA. 400-D.F. 1.1 (CEAEQ, 2015). The PCDDF value was

5 established by ng TEQ $\mathrm{kg}^{-1}$ (toxic equivalence) based on the toxicity equivalency factors (TEF)

6 and concentrations of 17 PCDDF congeners analyzed (NATO 1988).

\section{$7 \quad 3 \quad$ Results and Discussion}

\section{$8 \quad 3.1 \quad$ Soil characterization}

9 Table 1 presents a few basic parameters of the 1-4-mm J3 soil fraction and the initial 10 concentrations of both inorganic and organic contaminants. The $\mathrm{pH}$ value of this soil was quite 11 neutral $(\mathrm{pH}=7.15)$. The organic content in this fraction was relatively low, with a total organic

12 carbon concentration of $0.38 \%$, whereas the inorganic carbon content only represented $0.22 \%$.

13 The elemental analysis of this soil fraction revealed relatively low phosphorus, calcium, iron, 14 magnesium and potassium contents with values reaching 79, 3,452, 2,775, 2,447 and $49 \mathrm{mg} \mathrm{kg}^{-1}$, 15 respectively. This 1-4-mm soil fraction initially contained $15 \mathrm{mg} \mathrm{As} \mathrm{kg}^{-1}, 23 \mathrm{mg} \mathrm{Cr} \mathrm{kg}{ }^{-1}$,

$1652 \mathrm{mg} \mathrm{Cu} \mathrm{kg}^{-1}$, $9.5 \mathrm{mg} \mathrm{PCP} \mathrm{kg}^{-1}$ and 3,860 ng TEQ PCDDF kg-1. As this soil fraction contained 17 high concentrations of organic contaminants, an attrition process was applied to simultaneously 18 remove the inorganic and organic contaminants.

\section{$19 \quad 3.2$ Counter-current attrition process}

\section{3.2.1 Changes in the performance of the attrition process with the reuse of ATW}

21 The performances of an attrition process, consisting of five attrition steps and one rinsing step

22 and including the recycling of attrition effluents to reduce the consumption of water into the 
1 decontamination process, have been evaluated in the present study to determine if the effluents

2 can be recycled without any loss of the attrition process. During this study, the attrition

3 wastewater (ATW) was reused in the attrition process applied to the 1-4-mm J3 soil fraction over

415 loops (Fig. 1). The performances of both inorganic and organic contaminants removals have

5 been followed.

6 According to our results (values not shown), the metal removal yields obtained during 15 loops

7 of the CCAP including the treatment of ATW 1 by flocculation varied between 32 and $52 \%$ for

8 As, between 17 and 37\% for $\mathrm{Cr}$ and between 15 and 37\% for $\mathrm{Cu}$. These results showed that low

9 metal removal yields were obtained during the treatment of the 1-4-mm soil fraction by attrition,

10 which was due to the initial metal concentrations in the soil to be treated by CCAP being very

11 low: $15 \mathrm{mg} \mathrm{As} \mathrm{kg}^{-1}, 23 \mathrm{mg} \mathrm{Cr} \mathrm{kg}^{-1}$ and $52 \mathrm{mg} \mathrm{Cu} \mathrm{kg}^{-1}$. Furthermore, the attrition was performed

12 at $\mathrm{pH}=7$ and the dissolution of metals is not favored at neutral pH (Djedidi et al., 2009a, b). The

13 final metal concentrations measured in the treated soil over the 15 loops ranged from 7 to $10 \mathrm{mg}$

$14 \mathrm{As} \mathrm{kg}^{-1}$, from 14 to $19 \mathrm{mg} \mathrm{Cr} \mathrm{kg}^{-1}$ and from 33 to $44 \mathrm{mg} \mathrm{Cu} \mathrm{kg}$. However, even if the attrition

15 process showed low $\mathrm{As}, \mathrm{Cr}$ and $\mathrm{Cu}$ removal efficiencies from the 1-4-mm soil fraction, the final

16 concentrations of these metals in the soil fractions were very low, allowing the rehabilitation of

17 contaminated sites. However, these contaminants can become more problematic in the next few

18 years due to the potential increase of initial metals levels in soils due to some industrial

19 activities, it seemed important to follow the performances of this attrition process to ensure that

20 the sites can be efficiently rehabilitated.

21 Fig. 2 presents the final concentrations and the corresponding removal yields of PCP (Fig. 2a)

22 and PCDDF (Fig. 2b) measured in the 1-4-mm soil fraction obtained during the 15 loops of the

23 CCAP that included the treatment of ATW 1 by flocculation. According to the results presented 
1 in Fig. 2a, the removal yields obtained for the PCP ranged from 41 to 57\% with an average value

2 of $49 \pm 4 \%$. During the attrition process, PCP removal slightly decreased during loops 2 to 4

3 followed by an increase and then a stabilization of the PCP removal after loop 5. The PCP

4 concentrations measured in the final 1-4-mm soil fraction varied between 4.1 and $5.7 \mathrm{mg} \mathrm{kg}^{-1}$ in

5 the 15 loops of the CCAP. At the end of the CCAP, the average concentration of PCP measured

6 in the treated 1-4-mm soil fraction was approximately $4.8 \pm 0.4 \mathrm{mg} \mathrm{kg}^{-1}$, indicating that the

7 attrition process was quite efficient at removing this contaminant. These results support the

8 conclusion that the recirculation of the attrition wastewater does not reduce the removal

9 efficiency of PCP from the 1-4-mm soil fraction during the attrition process, as no loss of

10 efficiency was observed after 15 loops.

11 As shown in Fig. 2b, the PCDDF removal yields obtained during the CCAP varied between 41

12 and $50 \%$ during the 15 loops with an average value of $45 \pm 3 \%$. The residual concentrations of

13 PCDDF measured in the 1-4-mm soil fractions remained stable during loops 1 to 6 and then

14 decreased slightly during loops 6 to 14. The attrition process resulted in a decrease in

15 concentration of PCDDF in the 1-4-mm soil fraction from 3,900 ng TEQ $\mathrm{kg}^{-1}$ to an average of

$162,100 \pm 100 \mathrm{ng}$ TEQ $\mathrm{kg}^{-1}$ over 15 loops. According to these results, no loss of removal efficiency

17 of organic contaminants was observed after 15 loops of attrition wastewater recirculation.

18 Therefore, the recirculation of the effluents into the attrition process could be performed without

19 any loss of efficiency. Along the CCAP, a gradual increase in the amount of flocculation sludge

20 from 4.8 to $6.9 \mathrm{~g} \mathrm{~L}^{-1}$ (14 to $23 \mathrm{~g} \mathrm{~kg}^{-1}$ of the $1-4-\mathrm{mm}$ soil fraction) was observed during the

21 treatment of ATW 1 by flocculation-decantation. These results confirm that this treatment was

22 highly efficient at removing suspended matter from ATW 1, preventing the accumulation of

23 organic matter in attrition wastewater, which could have reduced the performance of the attrition 
1 process. According to all the results obtained, this CCAP can efficiently remove both organic

2 and inorganic contaminants from the 1-4-mm soil fraction, allowing the reduction of water

3 consumption.

\section{$4 \quad 3.2 .2$ Water consumption and mass balance}

5 The CCAP including the treatment of ATW 1 by flocculation is estimated to use $4.1 \mathrm{~m}^{3}$ of water

6 for the treatment of 1 metric ton of the 1-4-mm J3 soil fraction. Without recycling of the attrition

7 effluents, this process would require $18.5 \mathrm{~m}^{3}$ of water to treat 1 ton of the $1-4-\mathrm{mm} \mathrm{J3}$ soil

8 fraction. Therefore, the recycling of the attrition effluents resulted in a consumption of $4.1 \mathrm{~m}^{3} \mathrm{t}^{-1}$

9 and saves $14.5 \mathrm{~m}^{3} \mathrm{t}^{-1}$, leading to a reduction of $78 \%$ in water consumption, which results in a

10 great economic advantage for the CCAP. These results are comparable to those obtained in

11 previous works (Bisone et al., 2013 a, b; Lafond et al., 2013, 2014; Guemiza et al., 2014) that

12 showed the reduction of water consumption when recycling the effluents in a counter-current

13 leaching process and treating the leachates compared to a conventional process without the

14 recovery and recycling of effluents.

15 Table 2 shows the mass balance of the $15^{\text {th }}$ loop of the CCAP including the attrition process (five

16 attrition steps and one rinsing step) and the treatment of ATW 1 by flocculation. According to

17 our results, the output/input ratio (O/I) related to the dry 1-4-mm soil fraction was estimated to

18 be 0.91 . This indicated that $9 \%$ of the soil fraction was recovered as attrition sludge and

19 flocculation sludge after the five attrition steps. For the water, the O/I ratio was approximately

20 1.06, indicating that no water was lost during the process. The surfactant (BW) O/I ratio was

21 only 0.58 , indicating that $42 \%$ of the BW was not present in the attrition effluent (liquid phases)

22 but may be present in one of the solid phases including the remediated soil, attrition sludge

23 and/or flocculation sludge (cannot be quantified). For the metals, the O/I ratios were 
1 approximately $0.94,0.90$ and 0.87 for $\mathrm{As}, \mathrm{Cr}$ and $\mathrm{Cu}$, respectively. The $\mathrm{O} / \mathrm{I}$ ratios for PCP and

2 PCDDF were approximately 1.06 and 0.91 , respectively. These results showed good recoveries

3 of both inorganic and organic contaminants in both liquid and solid phases all along the CCAP.

\section{$4 \quad 3.3$ Optimization of removal of contaminants from attrition water}

5 The use of an attrition process to decontaminate the 1-4-mm soil fraction led to an increase in the

6 concentration of suspended organic matter and contaminants present in the attrition water

7 (ATW); this required treatment before being reused in the decontamination process. The attrition

8 water recovered from the first attrition step (ATW 1) following the solid/liquid separation

9 performed to remove the attrition sludge ( $1 \mathrm{~h}$ settling) was treated by chemical flocculation using

10 solutions of different organic polymers (Magnafloc 10, Magnafloc 1011, Magnafloc 919,

11 AMX 232, Zetag 7654, CTE 176, CMX 123, Percol 9511).

12 Table 3 presents the concentrations of suspended solids present in the effluent before (control)

13 and after treatment by flocculation using the same concentration $\left(0.02 \mathrm{~g} \mathrm{~L}^{-1}\right)$ of different cationic

14 or anionic polymers. According to the results, the addition of cationic polymers is more efficient

15 for the removal of suspended organic matter present in the ATW compared to the use of anionic

16 polymers. Indeed, the use of cationic flocculants (Zetag 7654, CTE 176, CMX 123 and

17 Percol 9511) achieved a removal of $91 \%$ - 93\% of the TSS, whereas inorganic polymers only

18 removed $27 \%-59 \%$ of TSS.

19 Additional experiments were carried out to evaluate the influence of the amount of cationic

20 flocculent added and the presence of a coagulant (chloride ferric) on the removal of TSS from

21 ATW 1. Table 4 presents the concentrations of TSS present in the supernatants after the

22 treatment of ATW 1 by coagulation/flocculation using different concentrations of cationic

23 polymers in the presence or absence of a coagulant (ferric chloride). These results show that an 
1 increase in the concentration of the flocculent from 0.02 to $0.04 \mathrm{~g} \mathrm{~L}^{-1}$ of ATW 1 led to increased

2 removal of suspended matter for all the flocculants studied. Indeed, up to 93, 96, 96, and 97\% of

3 TSS were removed in the presence of $0.04 \mathrm{~g} \mathrm{~L}^{-1}$ of Percol 9511, CTE 176, Zetag 7654 and

4 CMX 123, respectively, compared to 92, 91, 91 and $93 \%$ in the presence of $0.02 \mathrm{~g} \mathrm{~L}^{-1}$.

5 Moreover, the sludge obtained had solid contents varying from 5 to $7 \%$ for the assays performed

6 in the presence of Zetag 7654, CTE 176 and Percol 9511, whereas it reached approximately 15\%

7 in the presence of CMX 123. According to these results, the flocculation-decantation of

8 suspended matter present in ATW 1 is more favorable in the presence of $0.04 \mathrm{~g} \mathrm{CMX} 123 \mathrm{~L}^{-1}$

9 compared to other flocculants. The experiments performed in the presence and absence of a

10 coagulant show that the addition of a coagulant $\left(\mathrm{FeCl}_{3}\right)$ did not improve the removal of TSS

11 present in ATW 1. Indeed, an increase in the content of suspended matter was observed for the

12 experiments conducted in the presence of a coagulant $\left(0.93-0.99 \mathrm{~g} \mathrm{~L}^{-1}\right.$ in the presence of $\mathrm{FeCl}_{3}$

13 versus $0.05-0.12 \mathrm{~g} \mathrm{~L}^{-1}$ in the absence of $\mathrm{FeCl}_{3}$ ).

14 Three additional assays were carried out on $1 \mathrm{~L}$ of ATW 1 , using the best conditions $\left(0.04 \mathrm{~g} \mathrm{~L}^{-1}\right.$

15 of CMX 123, with no $\mathrm{FeCl}_{3}$ added). Tables 5 and 6 present the concentrations of TSS, both

16 inorganic and organic contaminants, and the concentrations of each PCDDF congener measured

17 in ATW 1 before and after flocculation, respectively. According to these results, the

18 concentration of TSS was reduced from $2.77 \mathrm{~g} \mathrm{~L}^{-1}$ to $0.09 \pm 0.01 \mathrm{~g} \mathrm{~L}^{-1}$, which corresponded to a

19 removal of $97 \%$. These results also show low $\mathrm{As}$, $\mathrm{Cr}$ and $\mathrm{Cu}$ removal yields ( $<45 \%)$, which can

20 be explained by the low metal contents initially measured in ATW 1 . The concentrations of PCP

21 and PCDDF measured in ATW 1 decreased from 0.85 to $0.33 \mathrm{mg} \mathrm{L}^{-1}$ and from 195 to

2212 ng TEQ L ${ }^{-1}$ after flocculation, respectively. The results presented in Table 6 show that 12 of

23 the 17 congeners considered to be toxic were initially present in ATW 1 . The removal yields 
1 obtained for the hexa-chlorinated, hepta-chlorinated and octa-chlorinated dioxins and furans

2 were very high, varying between $79 \%$ and $100 \%$, except for the 1,2,3,4,7,8-hexa-CDD (only

3 39\%). For the 1,2,3,7,8-penta-CDD, only 9\% was removed from ATW 1 using flocculation. The

4 final concentrations of both organic and inorganic contaminants didn't exceed $0.02 \mathrm{mg} \mathrm{L}^{-1}$ of As

5 and $\mathrm{Cr}, 0.23 \mathrm{mg} \mathrm{L}^{-1}$ of $\mathrm{Cu}, 0.33 \mathrm{mg} \mathrm{L}^{-1}$ of PCP and $12 \mathrm{ng}$ TEQ L ${ }^{-1}$ of PCDD/F; indicating that

6 the effluent can be recycled into the attrition process without any loss of process performances.

7 This treatment was quite efficient, achieving a removal of $97 \%$ of suspended matter, $61 \%$ of PCP

8 and 94\% of PCDDF. Therefore, the treatment of ATW 1 using flocculation seemed to be

9 advantageous for reducing the concentrations of contaminants and for allowing the reuse of the

10 wastewater in the attrition process.

\section{Conclusions}

13 The objective of this work was to remove the metals, PCP and PCDDF from a contaminated 1-4-

$14 \mathrm{~mm}$ soil fraction using a counter-current attrition process (CCAP), including the treatment of

15 ATW 1 by flocculation. The treatment of the attrition water (ATW 1) by flocculation in the

16 presence of a cationic polymer CMX 123 at $0.04 \mathrm{~g} \mathrm{~L}^{-1}$ seemed to be highly efficient for reducing

17 the concentrations of PCP (61\%) and PCDDF (94\%), with residual concentrations of

18 approximately $0.85 \mathrm{mg} \mathrm{PCP} \mathrm{L}^{-1}$ and $195 \mathrm{ng}$ TEQ PCDDF L ${ }^{-1}$. The results confirm that the CCAP

19 composed of five attrition steps (with conditions of tap water, $P D=40 \%\left(\mathrm{w} \mathrm{w}^{-1}\right),[B W]=2 \%$

$20\left(\mathrm{w} \mathrm{w}^{-1}\right), \mathrm{t}=20 \mathrm{~min}, \mathrm{~T}=20^{\circ} \mathrm{C}$ ) followed by one rinsing step can be successfully used without

21 affecting the performance of the attrition process in terms of the removal of metals, PCP and

22 PCDDF. Indeed, after 15 loops, the entire attrition process achieved an average removal of

$2344 \pm 5$ of As, $26 \pm 6$ of Cr, $24 \pm 5$ of $\mathrm{Cu}, 49 \pm 4$ of PCP and $45 \pm 3 \%$ of PCDDF. Moreover, 
1 compared to the conventional attrition process, the CCAP allowed for a reduction in the water

2 consumption by approximately $14.5 \mathrm{~m}^{3}$ per metric ton of the 1-4-mm soil fraction. Due to these

3 encouraging results, it can be concluded that this CCAP can be considered for industrial

4 application.

\section{Acknowledgments}

7 This work was supported by the Natural Sciences and Engineering Research Council of Canada

8 and IREQ under grant RDC 463019-14. The authors thank Myriam Chartier for her assistance. 
2 Bayley, R.W., and Biggs, C.A., 2005. Characterisation of an attrition scrubber for the removal of

\section{References} high molecular weight contaminants in sand. Chem. Eng. J., 111, 71-79.

4 Bisone, S., Mercier, G., and Blais, J.F., 2013a. Decontamination of metals and polycyclic 5

Bisone, S., Mercier, G., and Blais, J.F., 2013a. Decontamination of metals and polycyclic aromatic hydrocarbons from slag-polluted soil. Environ. Technol., 34, 2633-2648.

Bisone, S., Mercier, G., and Blais, J.F., 2013b. Counter-current metal leaching and precipitation for soil remediation. Soil Sediment Contamin., 22, 856-875.

CEAEQ, 2013. Détermination des composés phénoliques : dosage par chromatographie en phase gazeuse couplée à un spectromètre de masse après dérivation avec l'anhydride acétique. MA. 400-Phé 1.0, Rév. 3, Centre d’Expertise en Analyse Environnementale du Québec, Ministère du Développement Durable, de l’Environnement et des Parcs du Quebec, QC, Canada, 20 p.

CEAEQ, 2014a. Détermination du pH : méthode électrométrique. MA. 100 - pH 1.1, Centre d’Expertise en Analyse Environnementale du Québec, Ministère du Développement Durable, de l’Environnement et des Parcs du Quebec, QC, Canada, 11 p.

CEAEQ, 2014b. Détermination des métaux et du phosphore assimilables : méthode par spectrométrie de masse à source ionisante au plasma d’argon. MA. 200 - Mét-P ass. 1.0, Centre d’Expertise en Analyse Environnementale du Québec, Ministère du Développement Durable, de l’Environnement et des Parcs du Quebec, QC, Canada, 15 p.

21 CEAEQ, 2015. Détermination des dibenzo-para-dioxines polychlorés et dibenzofuranes 2 polychlorés : dosage par chromatographie en phase gazeuse couplée à un spectromètre de 
masse. MA. 400-D.F. 1.1, Centre d’Expertise en Analyse Environnementale du Québec, Ministère du Développement Durable, de l’Environnement et des Parcs du Québec, Quebec, QC, Canada, 33 p.

CEAEQ, 2015. Détermination des solides en suspension totaux et volatils : méthode gravimétrique. MA. 115 - S.S. 1.2, Centre d’Expertise en Analyse Environnementale du Québec, Ministère du Développement Durable, de l’Environnement et des Parcs du Quebec, QC, Canada, 11 p.

Chirenje, T., Ma, L.Q., Clark, C. and Reeves, M., 2003. Cu, Cr and As distribution in soils adjacent to pressure-treated decks, fences and poles. Environ. Pollut., 124, 407-417.

Coronas, M.V., Vaz Rocha, J.A., Favero Salvadori, D.M., and Ferrão Vargas, V.M., 2016. Evaluation of area contaminated by wood treatment activities: Genetic markers in the environment and in the child population. Chemosphere, 144, 1207-1215.

Dai, Q., Jiang, X., Wang, F., Chi, Y., and Yan, J., 2013. PCDD/Fs in wet sewage sludge using conventional and microwave heating. J. Anal. Appl. Pyrolysis, 104, 280-286.

Djedidi, Z., Bouda, M., Souissi, M.A., Ben Cheikh, R., Mercier, G., Tyagi, R.D., and Blais, J.F., 2009a. Metals removal from soil, fly ash and sewage sludge leachates by precipitation and dewatering properties of the generated sludge. J. Hazard. Mater., 172, 1372-1382.

Djedidi, Z., Bouda, M., Souissi, M.A., Ben Cheikh, R., Mercier, G., Tyagi, R.D., and Blais, J.F., 2009b. Comparative study of dewatering characteristics of metal precipitates generated during treatment synthetic polymetallic and AMD solutions. Hydrometallurgy, 98(3-4), 247-256. 
1 Guemiza, K., Mercier, G., and Blais, J.F., 2014. Pilot-scale counter-current acid leaching process

4 Guemiza, K., Coudert, L., Tran, L.H., Metahni, S., Blais, J.F., Besner, S., and Mercier, G., 2016. 5 for $\mathrm{Cu}, \mathrm{Pb}, \mathrm{Sb}$, and $\mathrm{Zn}$ from small-arms shooting range soil. J. Soils Sediments, 14, 13591369.

Optimizing removal of arsenic, chromium, copper, pentachlorophenol and polychlorodibenzo-dioxins/furans from the 1-4 $\mathrm{mm}$ fraction of polluted soil using an attrition process. Environ. Technol. doi: 10.1080/09593330.2016.1239658.

Han, F.X.X., Banin, A., Su, Y., Monts, D.L., Plodinec, M.J., Kingery, W.L., and Triplett, G.E., 2002. Industrial age anthropogenic inputs of heavy metals into the pedosphere. Naturwissenschaften, 89, 497-504.

Hedges, J.I., and Stern, J.H., 1984. Carbon and nitrogen determination of carbonate-containing solids. Limnol. Oceanogr., 29(3), 657-663.

Holt, E., Vetter, W., Symons, R., Weber, G., and Gaus, C., 2009. Assessing pesticides as a source of dioxins to the australian environment. Organhalogen Compounds, 71, 292-297.

Horizon Environnement. $2015 . \quad$ Horizon $\quad$ Environnnement. Website : http://www.horizonenviro.com/home, Accessed May 2015.

Hung, P.C., Chang, S.H., Ou-Yang, C.C., and Chang, M.B., 2016. Simultaneous removal of PCDD/Fs, pentachlorophenol and mercury from contaminated soil. Chemosphere, 144, 50-58.

Isosaari, P. Polychlorinated dibenzo-p-dioxin and dibenzofuran contamination of sediments and photochemical decontamination of soils. Ph.D. Thesis, University of Easern Finland, Kuopio, Finland, 95 p. 
1 Jobin, P., Coudert, L., Taillard, V., Blais, J.F., and Mercier, G., 2016. Remediation of inorganic

2 contaminants and polycyclic aromatic hydrocarbons from soils polluted by municipal

3 solid waste incinerator residues. Environ. Technol., 37(15), 1983-1995.

4 Jobin, P., Mercier, G., Blais, J.F., and Taillard, V., 2015. Understanding the effect of attrition 5 scrubbing on the efficiency of gravity separation of six inorganic contaminants. Water $6 \quad$ Air Soil Pollut., 226(5), 2422-2428.

7 Lafond, S., Blais, J.F., Mercier, G., and Martel, R., 2014. A counter-current acid leaching 8 process for the remediation of contaminated soils from a small-arms shooting rang. Soil $9 \quad$ Sediment Contamin., 23, 194-210.

10 Lafond, S., Blais, J.F., Martel, R., and Mercier, G., 2013. Chemical leaching of antimony and 11 other metals from small arms shooting range soil. Water Air Soil Pollut., 224, 1371-1386.

12 Lespagnol, G., 2003.Lixiviation du Cr, du Cu et de l’As (CCA) à partir de sols contaminés sur

Li, J., Sun, X., Yao, Z., and Zhao, X., 2014. Remediation of 1,2,3-tetrachlorobenzene des sites de traitement du bois, Ph.D. Thesis, École Nationale Supérieure des Mines de Saint-Étienne et de l’Université Jean Monnet, France, 213 p.

Liu, H., Park, J.W., and Haggblom, M.H., 2014. Enriching for microbial reductive dechlorination of polychlorinated dibenzo-p-dioxins and dibenzofurans. Environ. Pollut., 184, 222-230. in soil using nanosized particles of zerovalent iron and CaO. Chemosphere, 91, 740-744. 
1 Metahni, S., 2013. Décontamination à l'échelle pilote des sols pollués par des métaux, du

4 Metahni, S., Coudert, L., Chartier, M., Blais, J.F., Mercier, G., and Besner, S., 2016. Pilot-scale 5 pentachlorophénol et des dioxines et furanes. M.Sc. report, INRS-ETE, Université du Québec, Québec, QC, Canada, 179 p. decontamination of soil polluted with As, $\mathrm{Cr}, \mathrm{Cu}, \mathrm{PCP}$ and PCDDF by attrition and alkaline leaching. J. Environ. Eng. Div. ASCE, 143(9), 1-9.

NATO/CCMS (North Atlantic Treaty Organization, Committee on the Callenges of Modern Society). 1988. Pilot study on international information exchange on dioxins and related compounds. International Toxicity Equivalency Factor (I-TEF) method of risk assessment for complex mixtures of dioxins and related compounds. Report No. 176, $26 \mathrm{p}$.

Pohren, R.S., Rocha, J.A.V., Leal, K.A., and Vargas, V.M.F., 2012. Soil mutagenicity as a strategy to evaluate environmental and health risks in a contaminated area. Environ. Int., 44, 40-52.

Reynier, N., Blais, J.F., Mercier, G., and Besner, S., 2013a. Treatment of arsenic-, chromium-, copper- and pentachlorophenol-polluted soil using flotation. Water Air Soil Pollut., 224(4), 1514-1521.

Reynier, N., Blais, J.F., Mercier, G., and Besner, S. 2013b. Decontamination of metals, pentachlorophenol, and polychlorinated dibenzo-p-dioxins and dibenzofurans polluted. Environ. Technol., 35(1-4), 177-186. 
1 Riveiro-Huguet, M., and Marshall, W.D., 2011. Scaling up a treatment to simultaneously remove

4 Speir, T., Hannah, D., Kathiravelu, B., and Smart, R. 1997. Remediation of dioxin, 5 persistent organic pollutants and heavy metals from contaminated soils. Chemosphere, 83, 668-673. pentachlorophenol and organochlorine pesticide contaminated soils. Symposium No. 38Scientific registration, 1882, $7 \mathrm{p}$.

Thuan, N.T., Dien, N.T., and Chang, M.B., 2013. PCDD/PCDF behavior in low temperature pyrolysis of PCP-contaminated sandy soil. Sci. Total Environ., 443, 590-596.

Thuan, N.T., and Chang, M.B., 2012. Investigation of the degradation of pentachlorophenol in sandy soil via low-temperature pyrolysis. J. Hazard. Mater., 229-230, 411-418.

Tritz, A., Zeigler-Devin, I., Perrin, C., and Marquaire, P.M., 2014. Experimental study of the oxidation and pyrolysis of dibenzofuran at low concentration. J. Environ. Chemical Eng., 2, 143-153.

Tu, Y.T., Liu, J.K., Lin, W.C., Lin, J.L., and Kao, C.M., 2014. Enhanced anaerobic biodegradation of OCDD-contaminated soils by Pseudomonas mendocina NSYSU: Microcosm, pilot-scale, and gene studies. J. Hazard. Mater., 278, 433-443.

USEPA. 2004. Cleaning up the Nation's waste sites markets and technology trends, $4^{\text {th }}$ Edition. United States Environmental Protection Agency, Washington, DC, USA, 50 p.

Veetil, D.P., Mercier, G., Blais, J.F., Chartier, M., Tran, L.H., and Taillard, V., 2014. Remediation of contaminated dredged sediments using physical separation techniques. Soil Sediment Contamin., 23, 932-953. 
1 Wuana, R.A., and Okieimen, F.E., 2011. Heavy metals in contaminated soils: a review of sources, chemistry, risks and best available strategies for remediation. ISRN Ecol., 2011, $1-20$.

4 Young, C.A., Weston, R.F., Hatch, H., and Leibbert, J., 2000. On-site thermal desorption of 5 PCP- and dioxin-contaminated soil at the Coleman-Evans wood preservative site. 6 Whitehouse, Florida, USA, 11 p.

7 Zhao, L., Hou, H., Iwasaki, K., Terada, A., and Hosomi, M. 2013., Removal of PCDD/Fs from 8 contaminated sediment and released affluent gas by charcoal in a proposed cost-effective 9 thermal treatment process. Chemosphere, 93, 1456-1463.

10 Zhen, H., Du, S., Rodenburg, L.A., Mainelis, G., and Fennell, D., 2014. Reductive 11 dechlorination of 1,2,3,7,8-pentachlorodibenzo-p-dioxin and Aroclor 1260, 1254 and 1242 by a mixed culture containing Dehalococcoides mccartyi strain 195. Water Res., 52, 51-62. 


\section{Figure Caption List}

2 Fig. 1 Schematic representation of the counter-current attrition process (CCAP)

7 Fig. 2 including five attrition steps, a rinsing step and the treatment of the attrition water by flocculation performed on the 1-4-mm J3 soil fraction ([As $]_{0}=15 \mathrm{mg} \mathrm{kg}^{-1}$, $[\mathrm{Cr}]_{0}=23 \mathrm{mg} \mathrm{kg}^{-1},[\mathrm{Cu}]_{0}=52 \mathrm{mg} \mathrm{kg}^{-1},[\mathrm{PCP}]_{0}=9.5 \mathrm{mg} \mathrm{kg}^{-1},[\mathrm{PCDDF}]_{0}=$ 3,860 ng TEQ $\mathrm{kg}^{-1}$ )

PCP and PCDDF concentrations and the corresponding removal yields obtained during 15 loops of the counter-current attrition process (CCAP) on the 1-4-mm soil fraction, including the treatment of the attrition effluent by coagulation/flocculation (five attrition steps, $P D=40 \% \quad\left(\mathrm{w} \mathrm{w}^{-1}\right)$, $[\mathrm{As}]_{0}=15 \mathrm{mg} \mathrm{kg}^{-1},[\mathrm{Cr}]_{0}=23 \mathrm{mg} \mathrm{kg}^{-1},[\mathrm{Cu}]_{0}=52 \mathrm{mg} \mathrm{kg}^{-1},[\mathrm{PCP}]_{0}=9.5 \mathrm{mg} \mathrm{kg}^{-1}$, $[\mathrm{PCDDF}]_{0}=3,860 \mathrm{ng}$ TEQ $\mathrm{kg}^{-1}$ )

\section{Table Caption list}

Table 1 Soil parameters and contaminant contents measured in the 1-4 mm J3 soil fraction Table 2 Mass balance of the fifteenth cycle of counter current attrition process (CCLP) with attrition's effluent treatment including five attrition steps and one rinsing step

Table 3 Total suspended solids (TSS) concentrations $\left(\mathrm{g} \mathrm{L}^{-1}\right)$ measured in the supernatant emerging from the treatment of the attrition wastewater step 1 (ATW 1) performed in the presence of different flocculants at a concentration of $0.02 \mathrm{~g} \mathrm{~L}^{-1}$ 
4 Table 4 Residual concentration of suspended matter present in the effluent after treatment 5

(ATW 1 produced during the first step of attrition treatment performed using tap water, $\mathrm{PD}=40 \%\left(\mathrm{w} \mathrm{w}^{-1}\right),[\mathrm{BW}]=2 \%\left(\mathrm{w} \mathrm{w}^{-1}\right), \mathrm{t}=20 \mathrm{~min}, \mathrm{~T}=20^{\circ} \mathrm{C}$, fraction 1 $4 \mathrm{~mm}$ of the soil J3) of attrition wastewater step 1 (ATW 1) by coagulation/flocculation using different amounts of cationic polymers in the presence or the absence of coagulant $\left(\mathrm{FeCl}_{3}\right)$

Table 5 Concentrations of total suspended solids (TSS), metals, PCP and PCDDF present in the attrition wastewater step 1 (ATW 1) before and after treatment by flocculation in the presence of $0.04 \mathrm{~g} \mathrm{~L}^{-1}$ of a cationic polymer CMX 123

Table 6 Toxicity equivalency factor (TEF), concentrations (ng TEQ $\mathrm{L}^{-1}$ ), and removal yields (\%) obtained for each dioxin or furan congener present in attrition wastewater step 1 (ATW 1) before and after treatment by flocculation in the presence of a cationic polymer $\left([\mathrm{CMX} 123]=0.04 \mathrm{~g} \mathrm{~L}^{-1}\right)$ 


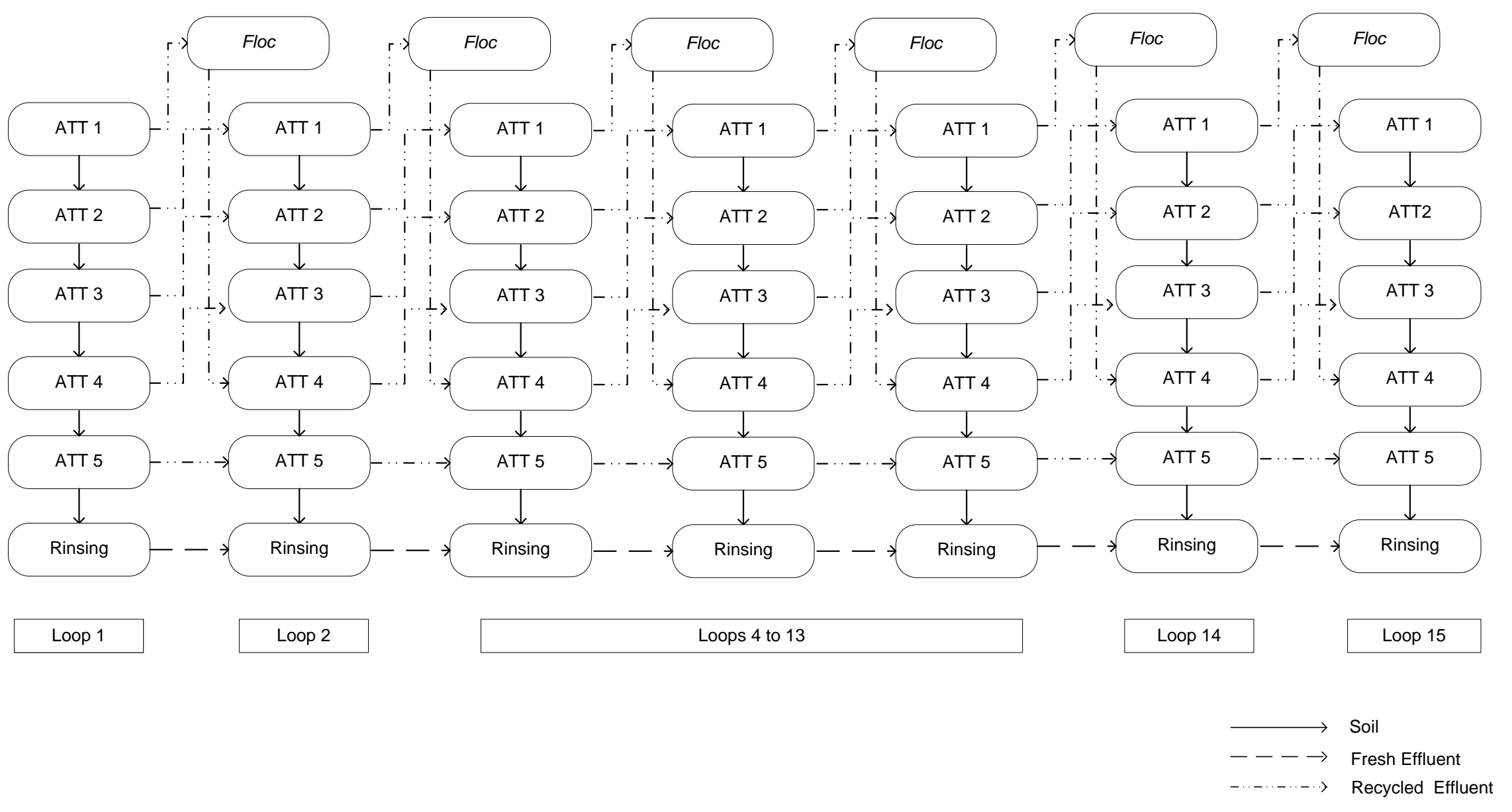

Figure 1 

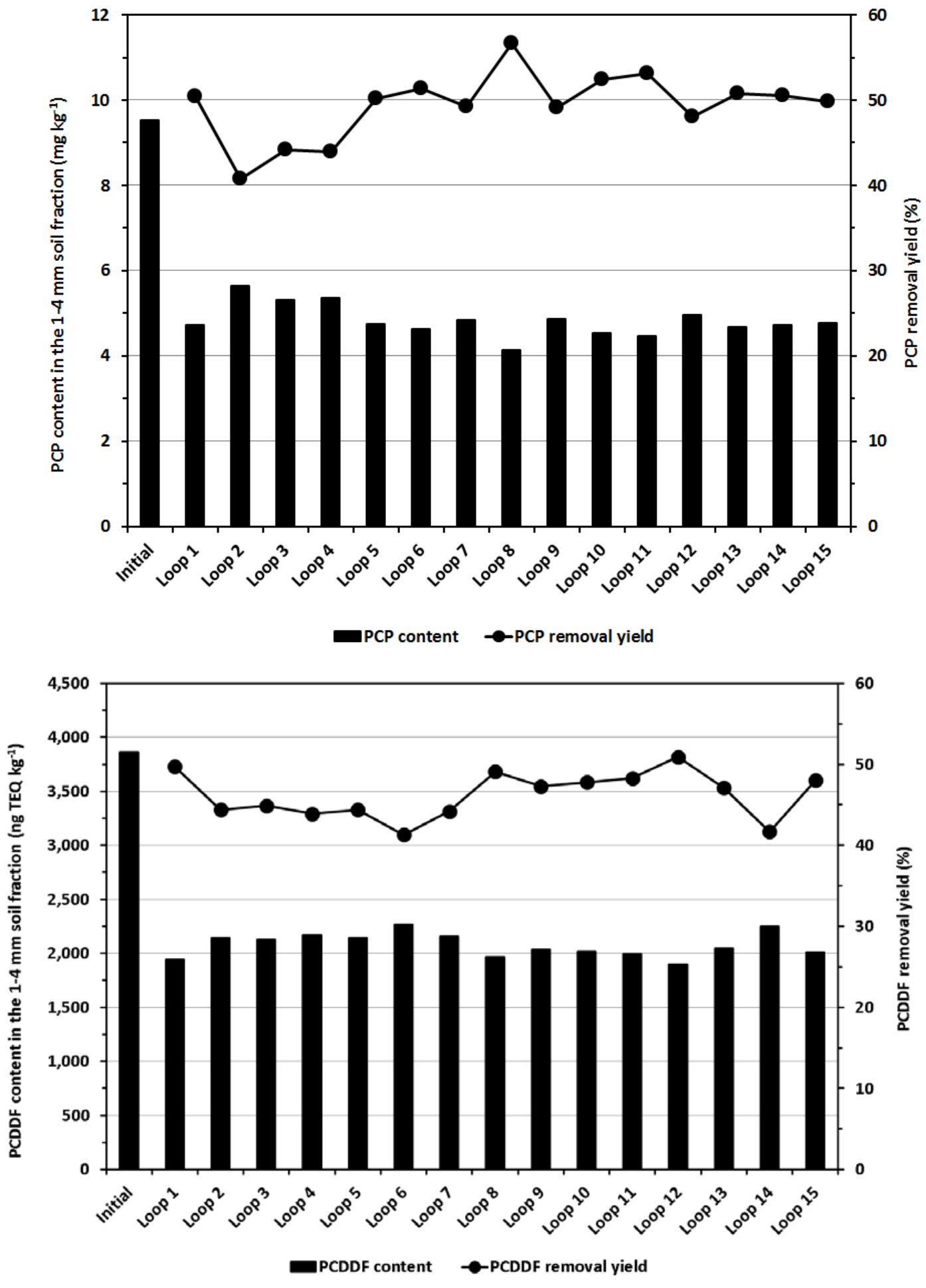

a.

b.

Figure 2 
Table 1 Soil parameters and contaminant contents measured in the $1-4 \mathrm{~mm} \mathrm{~J} 3$ soil fraction

\begin{tabular}{|c|c|}
\hline Soil & Values \\
\hline \multicolumn{2}{|l|}{ Parameters } \\
\hline $\mathrm{pH}$ in water at $25^{\circ} \mathrm{C}$ & 7.15 \\
\hline Total organic carbon (\%) & 0.38 \\
\hline Inorganic carbon (\%) & 0.22 \\
\hline \multicolumn{2}{|l|}{ Elements (mg kg ${ }^{-1}$ ) } \\
\hline $\mathrm{Ca}$ & 3,452 \\
\hline $\mathrm{Fe}$ & 2,775 \\
\hline K & 49 \\
\hline $\mathrm{Mg}$ & 2,447 \\
\hline$P$ & 79 \\
\hline \multicolumn{2}{|l|}{ Contaminants (mg kg $\left.{ }^{-1}\right)$} \\
\hline As & 15 \\
\hline $\mathrm{Cr}$ & 23 \\
\hline $\mathrm{Cu}$ & 52 \\
\hline PCP & 9.5 \\
\hline PCDDF (ng TEQ kg-1) & 3,860 \\
\hline
\end{tabular}


Table 2 Mass balance of the fifteenth cycle of counter current attrition process (CCLP) with attrition's effluent treatment including five attrition steps and one rinsing step

\begin{tabular}{|c|c|c|c|c|c|c|c|c|c|}
\hline & \multirow[t]{2}{*}{ Description } & \multirow{2}{*}{$\begin{array}{l}\text { Dry soil } \\
\text { (kg) }\end{array}$} & \multirow{2}{*}{$\begin{array}{l}\text { ATW } \\
\text { (L) }\end{array}$} & \multirow{2}{*}{$\begin{array}{l}\text { BW } \\
\text { (kg) }\end{array}$} & \multicolumn{5}{|c|}{ Quantity (mg) } \\
\hline & & & & & As & $\mathrm{Cr}$ & $\mathrm{Cu}$ & PCP & $\begin{array}{l}\text { PCDDF } \\
\text { (ng TEQ) }\end{array}$ \\
\hline \multirow[t]{2}{*}{ Input (I) } & Soil & 2.00 & & & 29.0 & 46.0 & 104 & 19.1 & 7,727 \\
\hline & Water & & 37.31 & 0.502 & 2.93 & 2.96 & 41.4 & 15.9 & 5,478 \\
\hline \multirow[t]{4}{*}{ Output (O) } & Soil & 1.82 & 0.20 & & 15.2 & 34.4 & 74.1 & 8.70 & 3,659 \\
\hline & Water & & 37.88 & 0.291 & 3.25 & 2.66 & 39.1 & 11.0 & 2,684 \\
\hline & Attrition sludge & & 1.35 & & 8.94 & 4.59 & 9.21 & 15.9 & 5,362 \\
\hline & $\begin{array}{l}\text { Flocculation } \\
\text { sludge }\end{array}$ & & 0.35 & & 2.54 & 2.34 & 4.24 & 1.54 & 364 \\
\hline $0 / 1$ & & 0.91 & 1.06 & 0.58 & 0.94 & 0.90 & 0.87 & 1.06 & 0.91 \\
\hline
\end{tabular}


Table 3 Total suspended solids (TSS) concentrations $\left(\mathrm{g} \mathrm{L}^{-1}\right)$ measured in the supernatant emerging from the treatment of the attrition wastewater step 1 (ATW 1) performed in the presence of different flocculants at a concentration of $0.02 \mathrm{~g} \mathrm{~L}^{-1}$ (ATW 1 produced during the first step of attrition treatment performed using tap water, $P D=40 \%\left(w w^{-1}\right),[B W]=2 \%\left(w w^{-1}\right), t=20 \mathrm{~min}$, $\mathrm{T}=20^{\circ} \mathrm{C}$, fraction $1-4 \mathrm{~mm}$ of the soil $\mathrm{J} 3$ )

\begin{tabular}{llll}
\hline Assays & Flocculent & Type & TSS $\left(\mathbf{g ~ L}^{-1}\right)$ \\
\hline Control & - & - & 1.61 \\
2 & Magnafloc 1011 & Anionic & 1.17 \\
3 & Magnafloc 919 & Highly anionic & 0.66 \\
4 & Magnafloc 10 & Anionic & 0.95 \\
5 & AMX 232 & Anionic & 1.39 \\
\hline 6 & CTE 176 & Cationic & 0.14 \\
7 & Percol 9511 & Highly cationic & 0.13 \\
8 & Zetag 7654 & Cationic & 0.15 \\
9 & CMX 123 & Cationic & 0.12 \\
\hline
\end{tabular}


Table 4 Residual concentration of suspended matter present in the effluent after treatment of attrition wastewater step 1 (ATW 1) by coagulation/flocculation using different amounts of cationic polymers in the presence or the absence of coagulant $\left(\mathrm{FeCl}_{3}\right)$

\begin{tabular}{|c|c|c|c|c|}
\hline Assays & Flocculent & $\begin{array}{l}\text { Flocculent added } \\
\text { (g L }{ }^{-1} \text { of ATW } 1 \text { ) }\end{array}$ & $\begin{array}{l}\text { Coagulant }\left(\mathrm{FeCl}_{3}\right) \\
\left(\mathrm{g} \mathrm{L}^{-1} \text { of ATW 1) }\right.\end{array}$ & $\begin{array}{l}\text { TSS } \\
\left(\mathrm{g} \mathrm{L}^{-1}\right)\end{array}$ \\
\hline Control & - & - & - & 1.62 \\
\hline 2 & Zetag 7654 & 0.02 & - & 0.15 \\
\hline 3 & Zetag 7654 & 0.04 & - & 0.06 \\
\hline 4 & Percol 9511 & 0.02 & - & 0.13 \\
\hline 5 & Percol 9511 & 0.04 & - & 0.11 \\
\hline 6 & CTE 176 & 0.02 & - & 0.14 \\
\hline 7 & CTE 176 & 0.04 & - & 0.07 \\
\hline 8 & CMX 123 & 0.02 & - & 0.12 \\
\hline 9 & CMX 123 & 0.04 & - & 0.05 \\
\hline 10 & CMX 123 & 0.06 & - & 0.06 \\
\hline 11 & CMX 123 & 0.02 & 0.5 & 0.99 \\
\hline 12 & CMX 123 & 0.04 & 0.5 & 0.93 \\
\hline 13 & CMX 123 & 0.06 & 0.5 & 0.99 \\
\hline
\end{tabular}


Table 5 Concentrations of total suspended solids (TSS), metals, PCP and PCDDF present in the attrition wastewater step 1 (ATW 1) before and after treatment by flocculation in the presence of $0.04 \mathrm{~g} \mathrm{~L}^{-1}$ of a cationic polymer CMX 123

\begin{tabular}{|c|c|c|c|c|c|c|}
\hline & TSS & As & $\mathrm{Cr}$ & $\mathrm{Cu}$ & PCP & PCDDF \\
\hline & $\left(\mathrm{g} \mathrm{L}^{-1}\right)$ & $\left(\mathrm{mg} \mathrm{L}^{-1}\right)$ & $\left(\mathrm{mg} \mathrm{L}^{-1}\right)$ & $\left(\mathrm{mg} \mathrm{L}^{-1}\right)$ & $\left(\mathrm{mg} \mathrm{L}^{-1}\right)$ & (ng TEQ L ${ }^{-1}$ ) \\
\hline Before & 2.77 & $0.03 \pm 0.02$ & $0.04 \pm 0.01$ & $0.28 \pm 0.01$ & 0.85 & 195 \\
\hline After & $0.09 \pm 0.01$ & $0.02 \pm 0.01$ & $0.02 \pm 0.01$ & $0.27 \pm 0.01$ & $0.33 \pm 0.01$ & $12.2 \pm 0.1$ \\
\hline Removal (\%) & $97 \pm 1$ & $26 \pm 3$ & $45 \pm 4$ & $3.4 \pm 0.4$ & $61 \pm 2$ & $94 \pm 1$ \\
\hline
\end{tabular}


Table 6 Toxicity equivalency factor (TEF), concentrations ( $\mathrm{ng}$ TEQ $\mathrm{L}^{-1}$ ), and removal yields (\%) obtained for each dioxin or furan congener present in attrition wastewater step 1 (ATW 1) before and after treatment by flocculation in the presence of a cationic polymer $\left([\mathrm{CMX} 123]=0.04 \mathrm{~g} \mathrm{~L}^{-1}\right)$

\begin{tabular}{|c|c|c|c|c|}
\hline Dioxin or furan congener & $\begin{array}{l}\text { Toxicity Equivalency Factor } \\
\text { (NATO 1988) }\end{array}$ & $\begin{array}{l}\text { Before } \\
\left(n g \text { TEQ L }{ }^{-1}\right)\end{array}$ & $\begin{array}{l}\text { After } \\
\left.\text { (ng TEQ L }{ }^{-1}\right)\end{array}$ & $\begin{array}{l}\text { Removal yield } \\
\text { (\%) }\end{array}$ \\
\hline $2,3,7,8$ Tetra-CDF & 0.10 & $<0.05$ & $<0.05$ & n.a ${ }^{*}$ \\
\hline 2,3,7,8 Tetra-CDD & 1.00 & $<1.62$ & $<1.60$ & n.a \\
\hline 1,2,3,7,8 Penta-CDF & 0.05 & $<0.06$ & $<0.06$ & n.a \\
\hline 2,3,4,7,8 Penta-CDF & 0.50 & $<0.50$ & $<0.50$ & n.a \\
\hline 1,2,3,7,8 Penta-CDD & 0.50 & 6.9 & 6.3 & 8.8 \\
\hline $1,2,3,4,7,8$ Неха-CDF & 0.10 & 2.7 & $<0.50$ & 100 \\
\hline $1,2,3,6,7,8$ Неха-CDF & 0.10 & $<0.20$ & $<0.20$ & $<0.2$ \\
\hline 1,2,3,7,8,9 Неха-CDF & 0.10 & 1.7 & $<0.31$ & 100 \\
\hline $1,2,3,4,7,8$ Hexa-CDD & 0.10 & 0.6 & 0.4 & 39 \\
\hline $1,2,3,6,7,8$ Hexa-CDD & 0.10 & 8.1 & $<0.50$ & 100 \\
\hline 1,2,3,7,8,9 Неxa-CDD & 0.10 & 3.7 & $<0.50$ & 100 \\
\hline 2,3,4,6,7,8 Hexa-CDF & 0.10 & 0.5 & 0.1 & 79 \\
\hline 1,2,3,4,6,7,8 Hepta-CDF & 0.01 & 9.0 & 0.6 & 94 \\
\hline $1,2,3,4,6,7,8$ Hepta-CDD & 0.01 & 74 & 2.8 & 96 \\
\hline $1,2,3,4,7,8,9$ Hepta-CDF & 0.01 & 1.0 & 0.1 & 89 \\
\hline Octa-CDD & 0.001 & 82 & 1.7 & 98 \\
\hline Octa-CDF & 0.001 & 5.1 & 0.3 & 95 \\
\hline Total (ng TEQ. L $^{-1}$ ) & - & 195 & 12 & 94 \\
\hline
\end{tabular}

*n.a: not applicable. 